\title{
Energy expenditure during flight in relation to body mass: effects of natural increases in mass and artificial load in Rose Coloured Starlings
}

\author{
Carola A. Schmidt-Wellenburg · Sophia Engel · \\ G. Henk Visser
}

Received: 18 December 2007/Revised: 18 March 2008/Accepted: 31 March 2008/Published online: 15 May 2008 (C) The Author(s) 2008

\begin{abstract}
Rose Coloured Starlings (Sturnus roseus) flew repeatedly for several hours in a wind tunnel while undergoing spontaneous variation in body mass. The treatments were as follows: flying unrestrained (U), with a control harness of $1.2 \%$ of their body mass (C), or with a harness of $7.4 \%$ of their body mass, which was either applied immediately before the flight $\left(\mathrm{L}_{\mathrm{S}}\right)$ or at least 9 days in advance $\left(L_{L}\right)$. Energy expenditure during flight $\left(e_{f}\right.$ in $\left.W\right)$ was measured with the Doubly Labelled Water method. Flight costs in $\mathrm{L}_{\mathrm{S}}$ and $\mathrm{L}_{\mathrm{L}}$ were not significantly different and therefore were pooled (L). The harness itself did not affect $e_{f}$, i.e. $U$ and $C$ flights were not different. $e_{f}$ was allometrically related with body mass $m$ (in $\mathrm{g}$ ). The slopes were not significantly different between the treatments, but $\mathrm{e}_{\mathrm{f}}$ was increased by $5.4 \%$ in $\mathrm{L}$ compared to $\mathrm{C}$ flights $\left(\log _{10}\left(\mathrm{e}_{\mathrm{f}}\right)=0.050+0.47 \times \log _{10}(m)\right.$ for $\mathrm{C}$, and $\log _{10}\left(\mathrm{e}_{\mathrm{f}}\right)=$ $0.073+0.47 \times \log _{10}(m)$ for $\left.\mathrm{L}\right)$. The difference in $\mathrm{e}_{\mathrm{f}}$ between $\mathrm{C}, \mathrm{L}_{\mathrm{S}}$ and $\mathrm{L}_{\mathrm{L}}$ was best explained by taking the transported mass $m_{\text {transp }}$ (in g) instead of $m$ into account $\left(\log _{10}\left(\mathrm{e}_{\mathrm{f}}\right)=-0.08+0.54 \times \log _{10}\left(m_{\text {transp }}\right)\right)$. Flight costs increased to a lesser extent than expected from interspecific
\end{abstract}

Communicated by G. Heldmaier.

C. A. Schmidt-Wellenburg $(\bowtie) \cdot$ S. Engel

Department of Biological Rhythms and Behaviour,

Max Planck Institute for Ornithology, Von-der-Tann-Str. 7,

82346 Andechs, Germany

e-mail: schmidt-wellenburg@orn.mpg.de

G. H. Visser

Zoological Laboratory, University of Groningen, PO Box 14,

9750 AA Haren, The Netherlands

G. H. Visser

Centre for Isotope Research, University of Groningen,

Nijenborgh 4, 9747 AG Groningen, The Netherlands allometric comparison or aerodynamic theory, regardless of whether the increase in mass occurred naturally or artificially. We did not observe an effect of treatment on breast muscle size and wingbeat frequency. We propose that the relatively low costs at a high mass are rather a consequence of immediate adjustments in physiology and/ or flight behaviour than of long-term adaptations.

Keywords Bird flight $\cdot$ Load · Flight costs · Body mass . Harness
Abbreviations
DLW Doubly labelled water
C Control
$\mathrm{e}_{\mathrm{f}} \quad$ Flight costs (in W)
$m \quad$ Body mass (in g)
$m_{\text {transp }} \quad$ Transported mass (in $\mathrm{g}$ )
L Loaded (with backpack)
$\mathrm{L}_{\mathrm{S}} \quad$ Short-term loaded, backpack applied immediately before the flight
$\mathrm{L}_{\mathrm{L}} \quad$ Long-term loaded, backpack applied at least 9 days in advance
$\mathrm{rH}_{2} \mathrm{O}_{\text {in }} \quad$ Water influx (in $\mathrm{g} \mathrm{day}^{-1}$ and $\mathrm{g} \mathrm{kg}^{-1}$ day ${ }^{-1}$, respectively)
$\mathrm{rH}_{2} \mathrm{O}_{\text {out }} \quad$ Water efflux (in $\mathrm{g} \mathrm{day}^{-1}$ and $\mathrm{g} \mathrm{kg}^{-1}$ day ${ }^{-1}$, respectively)
$\mathrm{TBW}_{\text {initial }}$ Total body water before a flight (in $\mathrm{g}$ )
$\mathrm{TBW}_{\text {final }}$ Total body water after a flight (in $\mathrm{g}$ )
$\mathrm{TBW}_{\% \text { initial }}$ Total body water before a flight (in \% of body mass)
$\mathrm{TBW}_{\% \text { final }}$ Total body water after a flight (in \% of body mass)
U Unrestrained
WBF Wing beat frequency (in $\mathrm{Hz}$ ) 


\section{Introduction}

Most migratory birds increase their body mass in preparation for long migratory flights, which results in higher flight costs (e.g. Pennycuick 1978). The extent of the increase of flight costs with body mass is important not only with regard to the actual nutritional status or immediate food requirements, but also to migration: flight distances, refuelling times, stopover duration, and successful completion of migration depend on energetic costs of flight and body mass. The relationship of energy expenditure during flight and body mass is used in models on optimal migration, which predict migratory strategies (e.g. Alerstam and Lindström 1990; Hedenström and Alerstam 1997; Weber and Houston 1997). Little direct information on the effect of body mass on flight costs is available. Three studies on Red Knots (Calidris canutus, Kvist et al. 2001), Rose Coloured Starlings (Sturnus roseus, Engel et al. 2006a) and Barn Swallows (Hirundo rustica, Schmidt-Wellenburg et al. 2007) have shown that at the individual level, carrying natural fuel loads such as fat or protein reserves during long flights is cheaper than expected from aerodynamic theory and from interspecific allometry (Butler and Bishop 2000; Masman and Klaassen 1987; Norberg 1996; Pennycuick 1978; Rayner 1990). It has been proposed that changes in flight muscle efficiency may accompany changes in body mass, both at the interspecific and the intraspecific level (Kvist and Lindström 2001; Rayner 1999, 2001; Ward et al. 2001). These changes in flight muscle efficiency may comprise (a) morphological and/or physiological as well as (b) behavioural changes. Morphological/physiological changes may include adjusted pectoral muscle size, changes in the muscle composition itself (Bauchinger and Biebach 2001), an improved supply of muscle cells with oxygen and nutrients, or higher density of mitochondria (Pennycuick and Rezende 1984). It is unknown, how much time it takes to develop one of these adaptations. However, studies on Pigeons (Columba livia) and Tree Sparrows (Passer montanus) report significant increases in muscle size within one week after overloading muscle experimentally (Mufti and Qureshi 1989; Lind and Jakobsson 2001). During stopover, birds may restore fuel loads within short periods: Red Knots were observed to stopover for 2.5-3.4 days, with an average fuel deposition rate of $2.8 \%$ of lean body mass per day (Helseth et al. 2005). Bauchinger et al. (2005) caught Garden Warblers (Sylvia borin) on migration and simulated stopover for 9 days. Towards the end of this period the mass gain stopped and the birds reached a stable body mass. During the simulated stopover, organs such as proventriculus, small intestine, liver, and kidneys increased in mass. Examples for behavioural changes are strain rate (wing beat frequency and/or wing beat amplitude), effective wing area (by stretching the wings more or less) and consequently a modification of wing loading, or the use of intermittent flight.

The studies available are all based on spontaneous changes in body mass. Here, we address the question of how naturally or artificially increased body mass affects flight costs, and whether birds can adjust instantaneously to an increased body mass or first have to develop this capability. We expect that a possible preparation effect (e.g. a change in fibre composition or in vascularisation of the muscle) would need time to develop, while modifications of flight behaviour might be immediate. We designed an experiment to quantify the effects of natural changes in body mass and artificial manipulation of transported mass on flight costs. We measured flight costs, body composition, water fluxes, changes in relative breast muscle thickness, and wing beat frequency in captive birds flying for several hours in the wind tunnel of the Max Planck Institute in Seewiesen, Germany (Engel 2005; Engel et al. 2006a). Individuals flew repeatedly with natural variations in body mass. Additionally, we manipulated the transported mass either directly before or 9 days prior to the experimental flight, which allowed us to discriminate between short-term behavioural adjustments and long-term morphological responses to increased mass.

We expected flight costs in birds with natural changes in body mass to allometrically scale with mass to the extent measured within species, i.e. to a lower extent than predicted from interspecific comparison and aerodynamic theory (Engel et al. 2006a; Kvist and Lindström 2001). We hypothesised that the artificial load increased flight costs relative to unrestrained flights to either (a) a higher extent in case the birds needed internal cues and/or time to "adjust" to the higher mass, or (b) to the same extent in case the adjustments were immediate, such as modification of flight behaviour.

\section{Materials and methods}

Birds, housing, and flight training

Energy expenditure during flight was measured in Rose Coloured Starlings. This is a migratory species with its breeding grounds stretching from the Balkans throughout Central Asia and wintering on the Indian subcontinent. During their seasonal migration, Rose Coloured Starlings cover about $5,000 \mathrm{~km}$ mainly in diurnal flights (Hudde 1993). We exploited their willingness to perform long flights of several hours during the migration periods, and measured energy expenditure during these flights with the 
DLW method during March-May 2001, October-December 2001, and March-May 2002.

We measured flight costs in 14 individuals. Four of these birds were purchased in 1999 as nestlings from a breeder and flown in U flights (see below) in 2001 (Engel et al. 2006a), and 10 birds were collected as nestlings from a breeding colony on the Crimea peninsula, Ukraine, in 2001, performing U flights in autumn 2001 and C and L flights (see below) in 2002. All Rose Coloured Starlings were hand raised at our institute and thus were familiar with close presence of humans and handling. The juvenile birds from the Ukraine were regularly trained to fly in the wind tunnel during 8 weeks before the first experimental flights. Adult birds had been flying in the wind tunnel before. They were trained for 3 weeks before the experimental flights in autumn 2001 and for 5 weeks in spring 2002. During training flights, as well as during the experiments, birds flew in groups of 2 to 3 , as the Rose Coloured Starling is a flock-living and also flock-migrating species, and the birds seemed to be more at ease in small groups than alone. However, they did not fly in any specific formation and changed their relative position in the wind tunnel frequently. During the weeks before an experimental flight, each bird had performed training flights of at least 90 min duration. All birds used in the experiment were in excellent condition without having any defects in their flight feathers.

The birds were housed in groups of $3-5$ in aviaries adjacent to the wind tunnel (ca. $1 \mathrm{~m} \times 2 \mathrm{~m} \times 2 \mathrm{~m}$ ). They received standard food, consisting of insects, beef heart, curd, rusk, and egg ad libitum supplemented with minerals and vitamins, some live mealworms and fresh fruit and salad. They had unlimited access to fresh water and the opportunity to bathe. The light schedule followed the conditions the birds would experience in the field: during winter, day length (from civil dawn to civil dusk) corresponded to the photoperiod of the wintering quarters in northern India $\left(27.5^{\circ} \mathrm{N}\right)$. During spring, it increased weekly until it met the natural day length at $47.5^{\circ} \mathrm{N}$ in summer, matching the light conditions at the natural breeding grounds as well as at our institute. During autumn, we gradually changed the day length back to the conditions at the wintering grounds. To approximate the spectral composition of natural sunlight, we used Osram Biolux ${ }^{\circledR}$ lamps.

\section{Experimental flights}

Fourteen Rose Coloured Starlings flew repeatedly (up to 9 times) in the wind tunnel of the Max Planck Institute for Ornithology, Seewiesen, Germany (Engel et al. 2006a). Between the flights, body mass of the birds varied spontaneously between 56.1 and $89.9 \mathrm{~g}$. Within individuals, variation in body mass (maximum-minimum) ranged from
2 to $30 \%$ of the minimum body mass (Fig. 1). During the experimental flights, birds flew either unrestrained (U), carried a control harness $(\mathrm{C})$, which was applied immediately before the flight, or a loaded harness (L), which was applied either immediately before the flight $\left(\mathrm{L}_{\mathrm{S}}\right)$ or at least 9 days before the experimental flight $\left(\mathrm{L}_{\mathrm{L}}\right.$; see below).

For individuals, the time interval between flights was on average $12.7 \pm 6.8$ days with a minimum interval of 5 days. The loaded harnesses increased the mass of the birds by $7.4 \pm 0.8 \%$ of the bird's body mass (with $7.5 \pm 0.9 \%$ in $\mathrm{L}_{\mathrm{S}}$ and $7.2 \pm 0.5 \%$ in $\mathrm{L}_{\mathrm{L}}$ flights). This artificial load of $7.4 \%$ was applied because a pilot phase had revealed that birds could immediately and sustainably fly with these loads but not with loads of $20 \%$ of the bird's body mass. To control for a potential increase in drag caused by the backpack birds in $\mathrm{C}$ flights were equipped with a very light harness, weighing on average $1.2 \pm 0.1 \%$ of the bird's body mass (ranging from 0.9 to $1.0 \mathrm{~g}$ ) and similar in volume and shape to the fully loaded harness. The construction of the harness was based on the thighmethod described in Rappole and Tipton (1991; Fig. 2). The harness was flat, had an even surface, and rested on the bird's lower back, the synsachrum. The additional mass was thus placed at the center of gravity, comparable to natural fuel loads. Feathers covered the anterior part of the harness and the loops. Because the harness was fixed at the bird's thighs, without loops around the neck or wings as in other studies (e.g. Gessaman et al. 1991; Godfrey 1970; Goldspink 1977; Higuchi et al. 1996; Nicholls and Warner 1968), the birds did not run the risk of dying from oesophageal blockage (Pekins 1996) and their flight ability was not impaired.

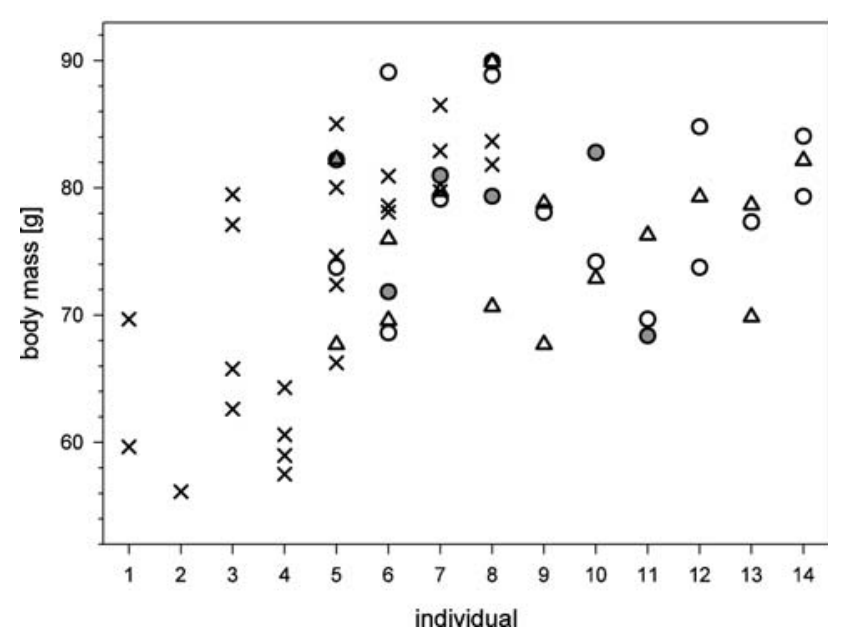

Fig. 1 Body mass characteristics and treatment of individuals during the experimental flights. We indicated the treatments at natural body mass (in g) for single individuals. Crosses refer to $\mathrm{U}$, triangles to $\mathrm{C}$, open circles to $\mathrm{L}_{\mathrm{S}}$, and grey circles to $\mathrm{L}_{\mathrm{L}}$ flights 


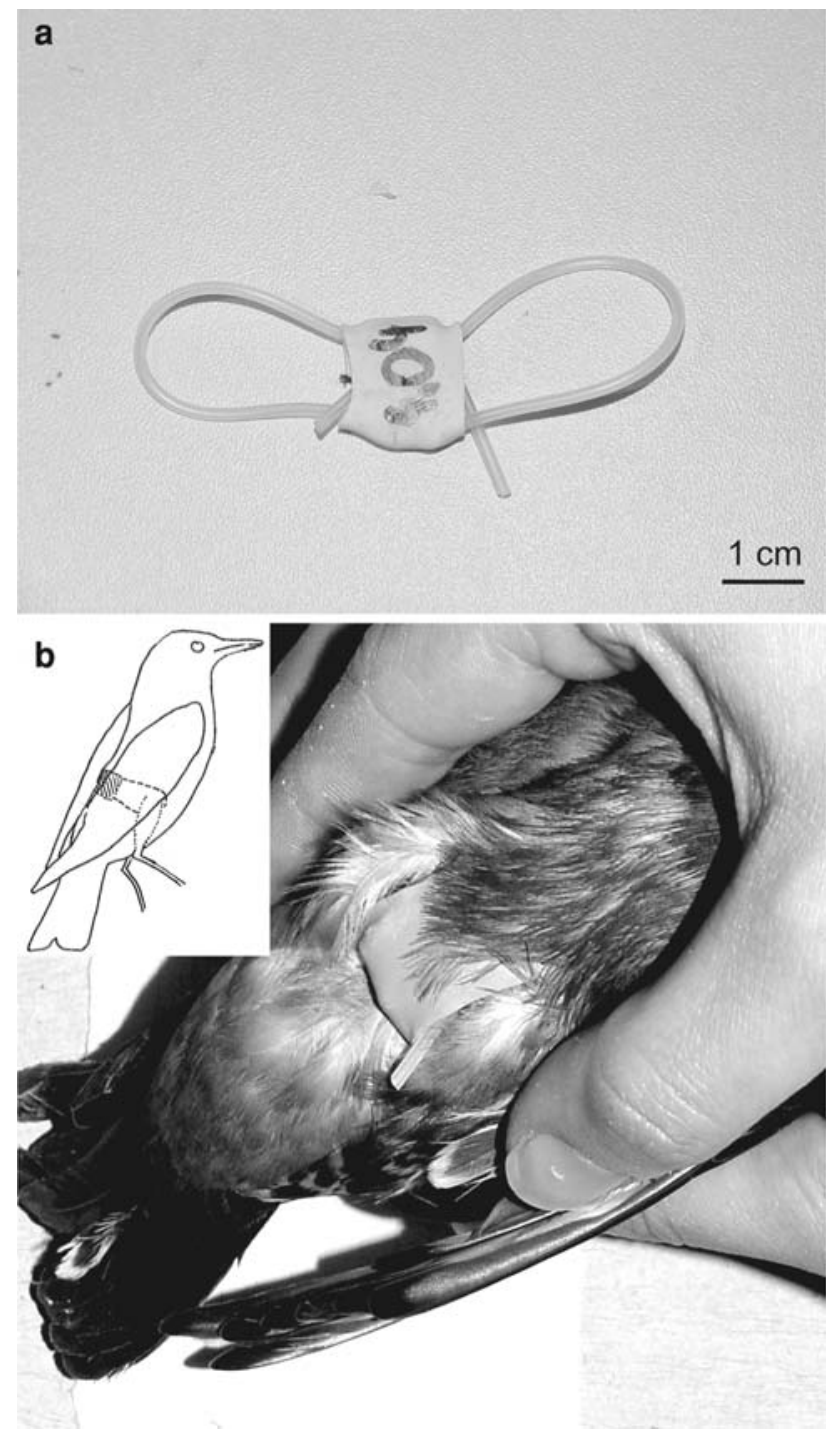

Fig. 2 a Harness. As a base, we used a piece of Styrofoam for C harnesses and lead for $\mathrm{L}$ harnesses. The material was sealed in a shrink hose. This "package" had a size of about $1.5 \mathrm{~cm} \times 1.5 \mathrm{~cm} \times$ $0.5 \mathrm{~cm}(w \times l \times h)$. For loops to be put around the birds' hips, we sewed silicone tubes with a diameter of $0.5 \mathrm{~cm}$ onto the shrink hose. b Harness applied to a bird's back and schematic drawing of the application

As in the training flights, birds flew in groups of 2 or 3 during experimental flights. Although they could land in the wind tunnel, even while the wind was switched on, an observer standing next to the flight section during the whole flight prevented the birds from landing or leaving the wind tunnel by waving at them when necessary. The mere presence of this person was usually sufficient. The birds were observed during the whole flight. When a bird landed frequently or refused to start again, we let it rest for at least $15 \mathrm{~min}$ or took it out of the experiment.

Flight speed was constant within all flights. In U flights, flight speed varied between the flights, with an average equivalent air speed of $11.2 \pm 1.5 \mathrm{~ms}^{-1}$ (SD $0.03 \mathrm{~ms}^{-1}$ within a flight, calculated from the internal data acquisition of the wind tunnel, sampling at a frequency of $1 \mathrm{~Hz}$ ). For all other flights, flight speed was adjusted to $11.0 \pm 0.0 \mathrm{~ms}^{-1}$. During the flights, birds covered on average $232.4 \pm 28.3 \mathrm{~km}$. Air temperature was set to $14.5 \pm 0.5^{\circ} \mathrm{C}$. The air pressure and relative humidity were not regulated $(937.9 \pm 8.9 \mathrm{mbar}$ and $58.3 \pm 10.3 \%$, respectively).

Energy expenditure during flight, $\mathrm{e}_{\mathrm{f}}$, and water flux

Energy expenditure during flight, $\mathrm{e}_{\mathrm{f}}$, was measured with the Doubly Labelled Water (DLW) method (Lifson and McClintock 1966; Speakman 1997). The accuracy of DLW measurements increases when birds are in a postabsorptive state, as they switch faster from carbohydrate to fat combustion (Rothe et al. 1987). Hence, birds were fooddeprived since the evening before the experimental flight in most of the measurements. For 8 of the U flights, birds had access to food in the morning before the experiment for about 60-90 min (Engel et al. 2006a). In the morning, shortly after lights on, we took a blood sample of about $60 \mu \mathrm{l}$ to determine the background concentration of ${ }^{18} \mathrm{O}$ and ${ }^{2} \mathrm{H}$ in the experimental bird. Afterwards, the bird was injected intraperitoneally with about $0.2 \mathrm{~g}$ of a DLW mixture (enriched in ${ }^{18} \mathrm{O}$ by 59.3 atom percent, and in ${ }^{2} \mathrm{H}$ by 34.5 atom percent). The injected dose was quantitatively determined by weighing the syringe on an analytical balance (Sartorius ${ }^{\circledR}$ BP1215) to the nearest $0.1 \mathrm{mg}$. After the injection, the bird was placed in a dark box without access to food or water for 1 hour. We then took another blood sample of $60 \mu$ (initial sample) from the jugular or the wing vein. From the dilution of the labelled isotopes with the body water pool, we calculated the bird's total body water before the experimental flight $\left(\mathrm{TBW}_{\text {initial }}\right.$, in $\left.\mathrm{g}\right)$. We took into account that calculations based on the isotope dilution method tend to overestimate TBW by $1.8 \%$ (Speakman et al. 2001). In treatment $\mathrm{C}$ and $\mathrm{L}_{\mathrm{S}}$, we applied the harness after the blood sample and immediately before the flight. After the flight, $6.0 \pm 0.49 \mathrm{~h}$ after the initial sample, the "final sample" of $60 \mu \mathrm{l}$ was taken. Thereafter, we removed the harness in all treatments $\left(\mathrm{C}, \mathrm{L}_{\mathrm{S}}\right.$, and $\left.\mathrm{L}_{\mathrm{L}}\right)$. We injected the bird with $0.11 \mathrm{~g}$ DLW afterwards, which was weighed to the nearest $0.1 \mathrm{mg}$. After one hour of rest in the dark box, we took another blood sample (reinjection sample) before the bird was released in its aviary, where it had access to food and water again.

The reinjection sample allowed us to calculate TBW at the end of an experimental flight $\left(\mathrm{TBW}_{\text {final }}\right)$, calculate exactly the water influx $\left(\mathrm{rH}_{2} \mathrm{O}_{\mathrm{in}}\right.$, in $\left.\mathrm{g} \mathrm{day}^{-1}\right)$ and water efflux $\left(\mathrm{rH}_{2} \mathrm{O}_{\text {out }}\right.$, in $\left.\mathrm{g} \mathrm{day}^{-1}\right)$ and thus increase the accuracy of the DLW measurement. We related both TBW and $\mathrm{rH}_{2} \mathrm{O}$ 
to body mass ( $\mathrm{TBW}_{\% \text { initial }}, \mathrm{TBW}_{\% \text { final }}$ (in \%), and $\mathrm{rH}_{2} \mathrm{O}_{\text {in }}$ and $\mathrm{rH}_{2} \mathrm{O}_{\text {out }}$ (in $\mathrm{g} \mathrm{kg}^{-1}$ day $^{-1}$ ), respectively) to account for possible differences in body size. The bird's body mass ( $m$ in $\mathrm{g}$ ) was determined to the nearest $0.01 \mathrm{~g}$ on a Sartorius ${ }^{\circledR}$ BL 1500S balance immediately before and after the flight. In the following, we always refer to the average body mass during flight.

All blood samples were subdivided over four capillary tubes, immediately flame-sealed, and stored at $5^{\circ} \mathrm{C}$ for the isotope analysis. The isotope analyses were performed in triplicate or quadruplicate at the Centre for Isotope Research according to the method described by Visser et al. (2000). Briefly, for each sample ${ }^{2} \mathrm{H} /{ }^{1} \mathrm{H}$ and ${ }^{18} \mathrm{O} /{ }^{16} \mathrm{O}$ isotope ratios were determined with the $\mathrm{CO}_{2}$ equilibration method and the uranium reduction methods, respectively (Speakman 1997). The coefficients of variation for ${ }^{18} \mathrm{O}$ and ${ }^{2} \mathrm{H}$ enrichments relative to the background levels were 1 and $0.75 \%$, respectively. Rates of $\mathrm{CO}_{2}$ production were calculated as described by Engel et al. (2006a). As a last step, these values were converted to energy expenditure using a conversion factor of $27.8 \mathrm{~kJ} \mathrm{l}^{-1}$ (Gessaman and Nagy 1988a; Engel et al. 2006b), assuming that $4 \%$ of the energy is derived from protein breakdown and the rest from fat. This fuel composition is in the range of empirical estimates for migrating birds (Jenni and Jenni-Eiermann 1998; Klaassen et al. 2000; Battley et al. 2001). Assuming the unlikely case that $10 \%$ of the energy is derived from protein breakdown would lead to an increase of $\mathrm{CO}_{2}$ production by $2 \%$. On average, the turnover rate of ${ }^{18} \mathrm{O}$ was 3.11 (SD 0.634) times higher than that for ${ }^{2} \mathrm{H}$. Consequently, an analytical error of $1 \%$ in the measured isotope values would result in an error of about $4 \%$ in the calculated energy expenditure.

As the DLW method integrates over the energy spent between the initial and the final blood sample, we corrected for the energy expenditure during non-flight, i.e. for resting and handling periods, with the mass-specific metabolic rate of $0.021 \mathrm{~W} \mathrm{~g} \mathrm{~g}^{-1}$ measured in postabsortive Rose Coloured Starlings during daytime at ambient temperatures above $12.9^{\circ} \mathrm{C}$ by Engel (2005) to yield the flight costs, $\mathrm{e}_{\mathrm{f}}$ (in W).

\section{Breast muscle index and Wing beat frequency (WBF)}

We assessed the "breast muscle index" before and after each flight by measuring the elevation of the muscle relative to the sternum at a standardized location to the nearest $0.01 \mathrm{~mm}$ with callipers (Fig. 3). This is a relative measure of muscle thickness. The first measurement of the breast muscle index was taken before the injection with DLW (henceforth referred to as initial breast muscle index), i.e. on average about $7.5 \mathrm{~h}$ before the last measurement after the flight. Three measurements were taken at each sampling time and averaged for further analysis. We measured the breast muscle index in the experimental birds of group $C, L_{S}$, and $L_{L}$. As a control for non-flight, we also measured it in 8 resting birds, which were kept under the same conditions except for the flight. The resting birds were measured in the morning and after about $7.9 \mathrm{~h}$, a time span comparable to that in the flying birds. During that time, the birds were kept without access to food and water, and, as in the experimental birds, three blood samples were taken. Body mass of these resting birds was on average $90.4 \pm 6.9 \mathrm{~g}$ during the measurement period.

WBF (in $\mathrm{Hz}$ ) was visually analysed from video recordings of the flight (watec WAT $-902 \mathrm{H}$ with 25 frames $\left.\mathrm{s}^{-1}\right)$. For a subsample of flights of treatments $\mathrm{C}(N=12)$, $\mathrm{L}_{\mathrm{S}}(N=12)$, and $\mathrm{L}_{\mathrm{L}}(N=6)$, we analysed flight sequences of $10 \mathrm{~s}$ duration and averaged over five such sequences as former analyses had revealed that WBF did not detectably change during flight (Engel et al. 2006a; Schmidt-Wellenburg et al. 2007). We evaluated the "effective" wing beat frequency, i.e. we allowed for periods of bounding and gliding flight.

\section{Statistics}

The statistical analyses were performed in SPSS 13.0. The tests were two-tailed, and significance was accepted at $P<0.05$. Data reported are averages $\pm \mathrm{SD}$ (between flights). To account for repeated measurements, we tested for effects of body mass $m$ (in $\mathrm{g}$ ) on $\mathrm{e}_{\mathrm{f}}$ (in $\mathrm{W}$ ) in linear mixed models with Restricted Maximum Likelihood (REML). Treatment (U, C, L, $\mathrm{L}_{\mathrm{S}}$, and $\mathrm{L}_{\mathrm{L}}$ ) was introduced to the analysis as a category, as the mass of the harness was correlated with $m$. The dependent variable was $\log _{10}\left(\mathrm{e}_{\mathrm{f}}\right)$; individuals were included as random, and $\log _{10}(m)$, treatment, treatment $\times \log _{10}(m)$, and $\log _{10}(\mathrm{WBF})$ as fixed factors. The interaction term and $\log _{10}$ (WBF) were excluded from the models in a stepwise manner, if they did not significantly contribute to the explained variance.

We tested for effects of the total mass transported in a flight $m_{\text {transp }}$ (in g), i.e. $m$ plus the mass of the harness, on $\mathrm{e}_{\mathrm{f}}$ in linear mixed models with REML as described above. As flight speed was shown to not significantly affect $e_{\mathrm{f}}$ in the $\mathrm{U}$ flights (Engel et al. 2006a), it was not included into the models. The effects of treatment and body mass on $\log _{10}(\mathrm{WBF})$ were tested in a separate linear mixed model, analogous to the model described above.

\section{Results}

We measured energetic costs of flight, $\mathrm{e}_{\mathrm{f}}$, in 65 flights by 15 individuals. Flight behaviour (i.e. if birds flew non-stop or interrupted the flight) had been shown to have a strong impact on the estimate of $e_{\mathrm{f}}$ (Schmidt-Wellenburg et al. 
Fig. 3 Callipers to measure the elevation of the breast muscle relative to the sternum.

Callipers and how they are used on a bird
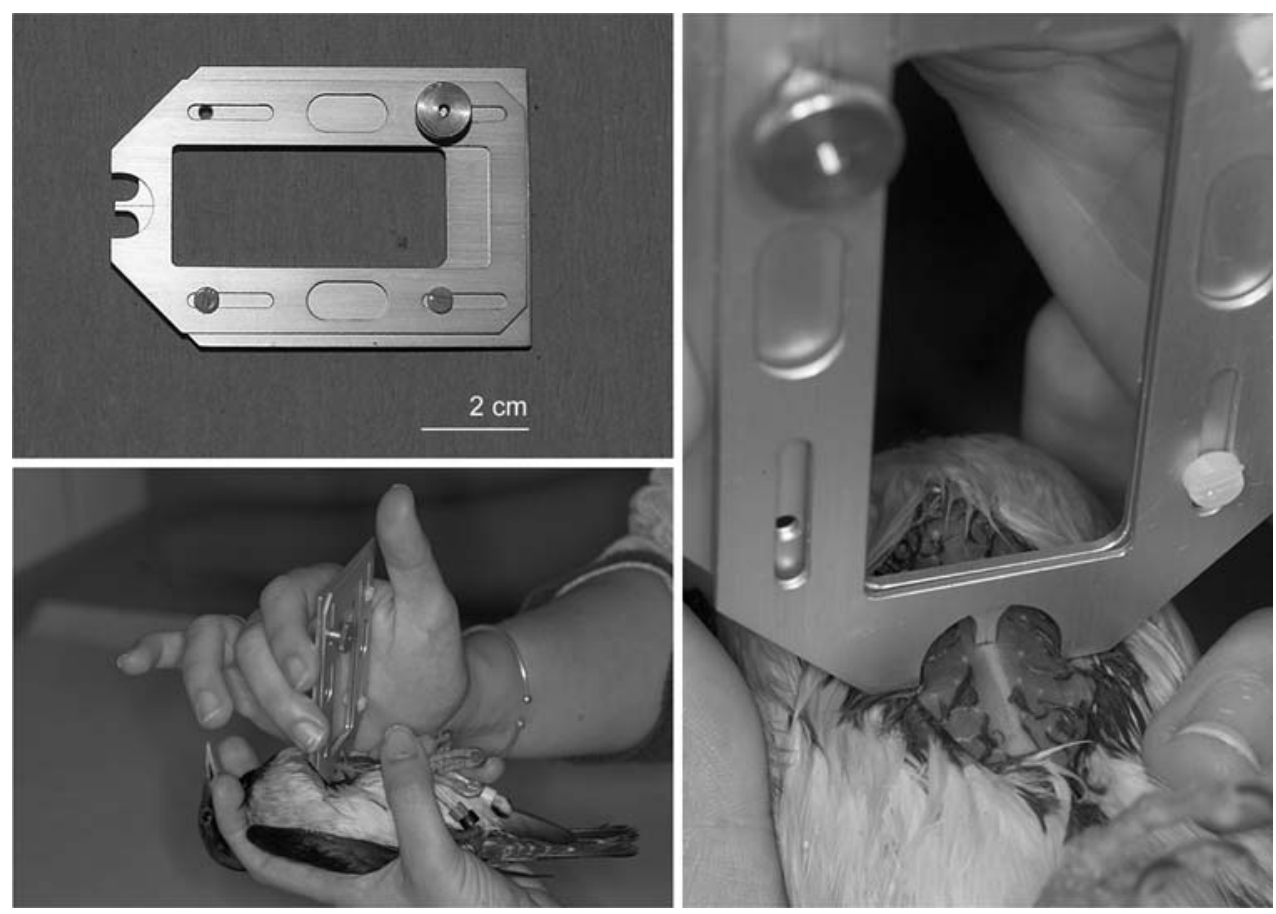

2007). We therefore excluded interrupted flights (i.e. 4 U, 1 $\mathrm{C}$, and $1 \mathrm{~L}_{\mathrm{S}}$ flight) and restricted the analysis to the 59 nonstop flights. In these flights, birds flew on average for $5.8 \pm 0.5 \mathrm{~h}$, or during $94.9 \pm 2.0 \%$ of the time measured with the Doubly Labelled Water Method. The estimated energy expenditure during non-flight accounted for $1.0 \pm 0.4 \%$ (range $0.3-2.3 \%$ ) of the total amount of energy spent during a session.

Eight individuals performed 24 flights without an artificial load (U). Mean body mass during these flights was $72.6 \pm 9.9 \mathrm{~g}$ and ranged from 56.1 to $86.5 \mathrm{~g}$. During $\mathrm{U}$ flights, $e_{\mathrm{f}}$ was $8.08 \pm 0.75 \mathrm{~W}$, ranging from 6.58 to $9.17 \mathrm{~W}$. Ten individuals flew in C treatments (15 flights). Average body mass during these flights was $76.1 \pm 6.4 \mathrm{~g}$, ranging from 67.7 to $89.9 \mathrm{~g}$, and flight costs were $8.56 \pm 0.60 \mathrm{~W}$ (ranging from 7.60 to $9.42 \mathrm{~W}$ ). Ten individuals in 20 flights carried an artificial load, with 10 birds flying 14 times in treatment $L_{S}$ and 6 individuals flying 6 times in treatment $\mathrm{L}_{\mathrm{L}}$. Body mass during $\mathrm{L}$ flights was $78.8 \pm 6.7 \mathrm{~g}$ (ranging from 68.4 to $89.9 \mathrm{~g}$ ), and $\mathrm{e}_{\mathrm{f}}$ was $9.17 \pm 0.82 \mathrm{~W}$ (ranging from 7.72 to $10.75 \mathrm{~W}$ ).

In general, there was a positive association of $\mathrm{e}_{\mathrm{f}}$ with body mass (Fig. 4 ). In the presence of $\log _{10}(m)$, the interaction term $\log _{10}(m) \times$ treatment did not significantly reduce the observed variance of $\log _{10}\left(\mathrm{e}_{\mathrm{f}}\right)$ and was therefore excluded from the models. $\mathrm{C}$ flights did not differ significantly from $U$ flights, i.e. the harness itself did not affect $e_{f}$ (Table 1a). Flight costs in the $\mathrm{U}$ and $\mathrm{C}$ flights scaled as (Table 1b)

$\log _{10}\left(\mathrm{e}_{\mathrm{f}}\right)=-0.149+0.57 \times \log _{10}(m)$

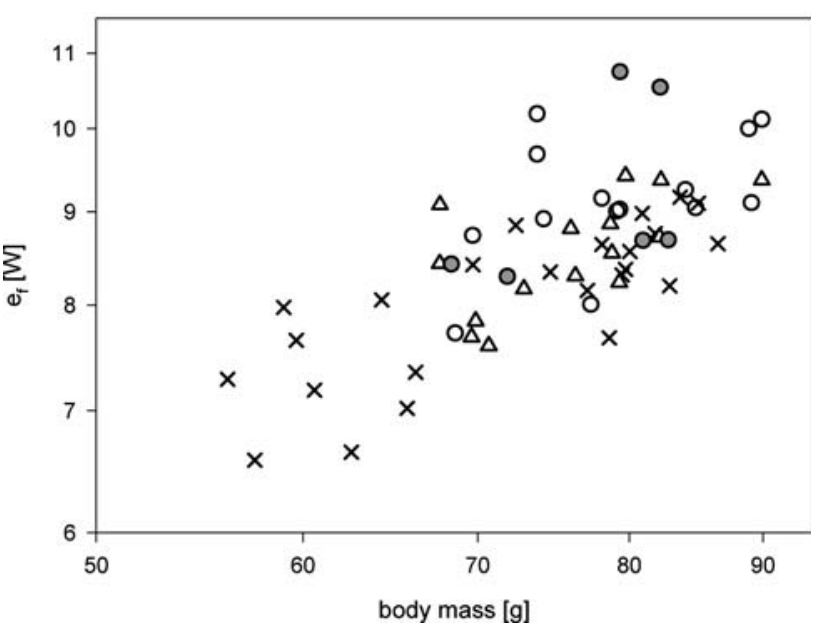

Fig. 4 Energy expenditure during flight $\left(\mathrm{e}_{\mathrm{f}}\right.$ in $\left.\mathrm{W}\right)$ in relation to body mass ( $m$ in $\mathrm{g}$ ) on a double logarithmic scale. Crosses refer to $\mathrm{U}$, triangles to $\mathrm{C}$ flights, open circles to $\mathrm{L}_{\mathrm{S}}$, and grey circles to $\mathrm{L}_{\mathrm{L}}$ flights

For further analyses of the energetic costs of flight, we excluded U flights, as they were not performed in all birds. We therefore took the $\mathrm{C}$ flights as the baseline for comparisons between the different treatments of the ten other birds (Fig. 1).

We separately tested for an effect of the duration of the load application by comparing $\mathrm{L}_{\mathrm{S}}$ and $\mathrm{L}_{\mathrm{L}}$ flights. We did not detect a difference in the allometric scaling between the two treatments (Table 1c). The two groups were pooled to form the $\mathrm{L}$ group for further analysis. In a next step, costs of flight were compared between $\mathrm{L}$ and $\mathrm{C}$ treatments. The 
Table 1 The effect of $\log _{10}(m)$ and treatment on $\log _{10}\left(\mathrm{e}_{\mathrm{f}}\right)$
$N_{\mathrm{U}}=24$ in 8 individuals,

$N_{\mathrm{C}}=15$ in 10 individuals,

$N_{\mathrm{LS}}=14$ in 10 individuals,

$N_{\mathrm{LL}}=6$ in 6 individuals,

$N_{\text {no-L }}=39$ in 10 individuals,

$N_{\mathrm{L}}=20$ in 10 individuals

${ }^{a}$ used as reference for the other treatment effects

\begin{tabular}{|c|c|c|c|c|c|}
\hline Explanatory variable & Data & Estimated effect & $F$ & $P$ & $95 \% \mathrm{CI}$ \\
\hline (a) & $\mathrm{U}, \mathrm{C}$ & & & & \\
\hline Intercept & & -0.108 & $F_{1,28.2}=0.434$ & & \\
\hline $\log _{10}(m)$ & & 0.546 & $F_{1,27.9}=44.136$ & $<0.001$ & 0.377 to 0.714 \\
\hline \multirow[t]{3}{*}{ treatment } & & & $F_{1,35.9}=2.399$ & 0.130 & \\
\hline & $\mathrm{U}$ & $0^{\mathrm{a}}$ & & & \\
\hline & $\mathrm{C}$ & 0.013 & & & \\
\hline (b) & $\mathrm{U}, \mathrm{C}$ & & & & \\
\hline Intercept & & -0.149 & $F_{1,27.3}=0.933$ & & \\
\hline $\log _{10}(m)$ & & 0.571 & $F_{1,27.1}=47.390$ & $<0.001$ & 0.401 to 0.741 \\
\hline (c) & $\mathrm{L}_{\mathrm{s}}, \mathrm{L}_{\mathrm{L}}$ & & & & \\
\hline Intercept & & 0.442 & $F_{1,10.8}=1.905$ & 0.195 & \\
\hline $\log _{10}(m)$ & & 0.274 & $F_{1,10.8}=2.629$ & 0.134 & \\
\hline \multirow[t]{3}{*}{ treatment } & & & $F_{1,9.0}=0.066$ & 0.802 & \\
\hline & $\mathrm{L}_{\mathrm{L}}$ & $0^{\mathrm{a}}$ & & & \\
\hline & $\mathrm{L}_{\mathrm{s}}$ & -0.003 & & & -0.029 to 0.023 \\
\hline (d) & $\mathrm{C}, \mathrm{L}$ & & & & \\
\hline Intercept & & 0.050 & $F_{1,31.1}=0.054$ & & \\
\hline $\log _{10}(m)$ & & 0.468 & $F_{1,31.1}=10.955$ & $<0.01$ & 0.180 to 0.757 \\
\hline \multirow[t]{3}{*}{ treatment } & & & $F_{1,25.7}=5.637$ & $<0.05$ & \\
\hline & $\mathrm{C}$ & $0^{\mathrm{a}}$ & & & \\
\hline & $\mathrm{L}$ & 0.023 & & & 0.0003 to 0.043 \\
\hline
\end{tabular}

slopes were not significantly different, but birds in treatment $\mathrm{L}$ used more energy during flight (Fig. 5a; Table 1d). From this simultaneous analysis, the relationship between energy expenditure during flight, $\mathrm{e}_{\mathrm{f}}$ (in $\mathrm{W}$ ), and natural body mass, $m$ (in $\mathrm{g}$ ), is best described by

$\log _{10}\left(\mathrm{e}_{\mathrm{f}}\right)=-0.050+0.47 \times \log _{10}(m)$

for $\mathrm{C}$ flights, and by

$\log _{10}\left(\mathrm{e}_{\mathrm{f}}\right)=-0.073+0.47 \times \log _{10}(m)$

for L flights.

This indicates an elevation of $\mathrm{e}_{\mathrm{f}}$ by $5.4 \%$ in L compared to $\mathrm{C}$ flights (Table 1d; Fig. 5a).

When we accounted for the mass added by the harness (1.2 or $7.4 \%$ of the birds' natural body mass) and related $e_{f}$ to the actually transported mass $m_{\text {transp }}$ (in $\mathrm{g}$ ) instead of the natural body mass $m$, we did not observe any significant effects of treatment on $\mathrm{e}_{\mathrm{f}}$ (Table 2; Fig. 5b). The relation was best described as

$\log _{10}\left(\mathrm{e}_{\mathrm{f}}\right)=-0.080+0.54 \times \log _{10}\left(m_{\text {transp }}\right)$

TBW was $45.1 \pm 3.5 \mathrm{~g}(N=59)$ before and $43.2 \pm 3.4 \mathrm{~g}$ after the flights. Consequently, water efflux, $\mathrm{rH}_{2} \mathrm{O}_{\text {out }}$, was higher $\left(31.3 \pm 7.0 \mathrm{~g} \mathrm{day}^{-1}\right)$ than water influx, $\mathrm{rH}_{2} \mathrm{O}_{\text {in }}$ $\left(23.0 \pm 4.5 \mathrm{~g} \mathrm{day}^{-1}\right)$. Neither TBW when expressed as a percentage of the birds' body mass $\left(\mathrm{TBW}_{\%}\right)$ nor massspecific water flux (in $\mathrm{g} \mathrm{kg}^{-1} \mathrm{day}^{-1}$ ) differed between the treatments (Fig. 6).
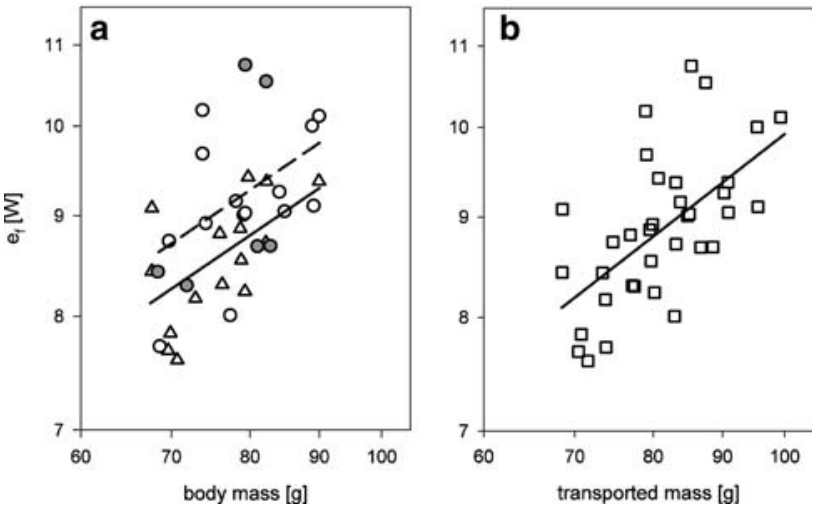

Fig. 5 Energy expenditure during flight $\left(e_{\mathrm{f}}\right.$ in W) in relation to (a) body mass $m$ (in g) and to (b) transported mass $m_{\text {transp }}$ (in g) on a double logarithmic scale. a Triangles refer to $\mathrm{C}$, open circles to $\mathrm{L}_{\mathrm{S}}$, and grey circles to $\mathrm{L}_{\mathrm{L}}$ flights. The regression fitted to $\mathrm{C}$ flights is solid (Eq. 2.1) and the one fitted to L flights is dashed (Eq. 2.2). b The regression is fitted to all data, represented as squares $\left(C, L_{s}\right.$ and $L_{L}$; Eq. 3)

The initial breast muscle index was $5.34 \pm 0.57 \mathrm{~mm}$ in flying $(N=35)$ and $5.57 \pm 0.42 \mathrm{~mm}$ in resting birds $(N=8)$. With regard to a possible adjustment to an increased load, we did not observe a difference in initial breast muscle index between $\mathrm{L}_{\mathrm{S}}$ and $\mathrm{L}_{\mathrm{L}}$ treatments (MannWhitney $U=40.0$, Wilcoxon $W=61.0, Z=-0.165$, $P>0.05)$. After either a flying or a fasting session, the breast muscle index had decreased significantly (Fig. 7, 


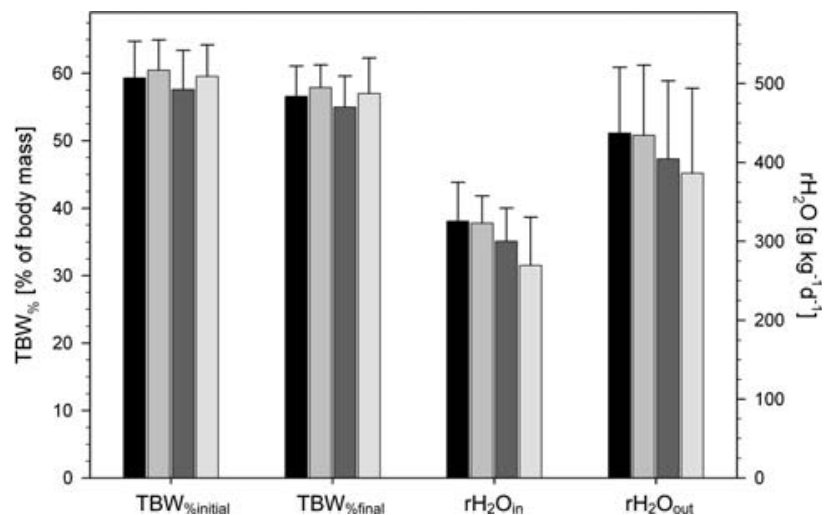

Fig. 6 Total Body Water $\left(\mathrm{TBW}_{\% \text { initial }}\right.$ and $\mathrm{TBW}_{\% \text { final }}$, in \% of body mass) and water flux $\left(\mathrm{rH}_{2} \mathrm{O}_{\text {in }}\right.$ and $\mathrm{rH}_{2} \mathrm{O}_{\text {out }}$, in $\mathrm{g} \mathrm{kg}^{-1}$ day $\left.^{-1}\right)$. Depicted are the averages $(+\mathrm{SD})$ per treatment, with black bars for U, grey for $\mathrm{C}$, dark grey for $\mathrm{L}_{\mathrm{S}}$ and light grey for $\mathrm{L}_{\mathrm{L}}$ flights

Wilcoxon Signed Ranks Test, $Z=-4.842, P<0.001$, $N=43$ ). In flying birds, the level of decrease was not significantly different between $\mathrm{L}$ and $\mathrm{C}$. There was also no difference in the decrease between flying birds and resting birds. All birds exhibited similar changes in the breast muscle index irrespective of the treatment.

The loss of body mass relative to the initial body mass during a flying or a fasting session in $\mathrm{U}, \mathrm{C}, \mathrm{L}_{\mathrm{S}}, \mathrm{L}_{\mathrm{L}}$, and resting birds was $6.81 \pm 1.21,7.32 \pm 0.83,7.60 \pm 1.03$, $7.49 \pm 1.18$, and $3.73 \pm 0.70 \%$, respectively. There was no statistically significant difference with regard to the treatments of flying birds on body mass loss (treatment (no$\mathrm{L}$ and $\mathrm{L}$ ): $\left.F_{1,56.0}=3.65, P=0.061\right)$. However, mass loss was significantly lower in resting than in flying birds $\left(F_{1,35.3}=102.65, P<0.001,95 \%\right.$ CI $\left.2.96-4.45 \%\right)$.

Effective wing beat frequency WBF was $8.32 \pm 0.82 \mathrm{~Hz}$ in $\mathrm{C}$ flights $(N=12), 8.88 \pm 1.06 \mathrm{~Hz}$ in $\mathrm{L}_{\mathrm{S}}(N=12)$ and $8.33 \pm 0.64 \mathrm{~Hz}$ in $\mathrm{L}_{\mathrm{L}}$ flights $(N=6$; Fig. 8). WBF did not explain $\mathrm{e}_{\mathrm{f}}$ (Pearson Correlation $=0.320, P>0.05, N=30$ ). It was not dependent on treatment, but on mass alone. Testing for the effect of natural body mass $m$ and transported mass $m_{\text {transp }}$ yielded similar results, and the percentage of the explained

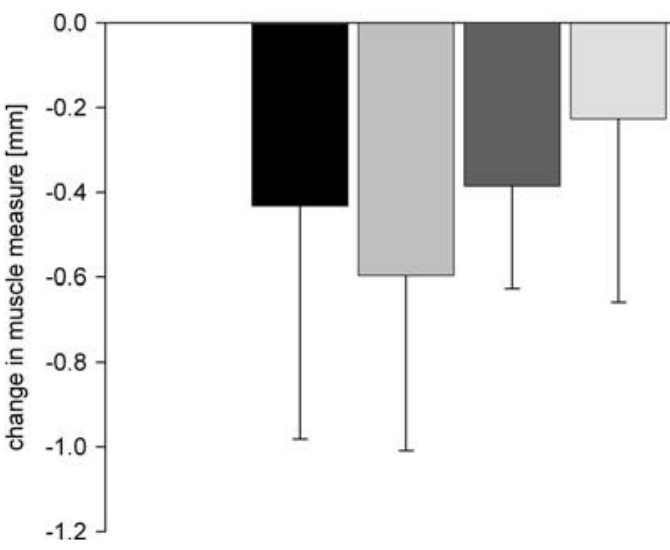

Fig. 7 Changes in breast muscle index (in $\mathrm{mm}$ ). Average changes ( $-\mathrm{SD}$ ) during $\mathrm{C}$ (black), $\mathrm{L}_{\mathrm{S}}$ (grey), and $\mathrm{L}_{\mathrm{L}}$ flights (dark grey) and in resting birds (light grey)

variance was not different between the models. The allometric scaling of WBF can be best described as

$\log _{10}(\mathrm{WBF})=0.20+0.38 \times \log _{10}\left(m_{\text {transp }}\right)$.

The $95 \% \mathrm{CI}$ for the factor was $0.036-0.723\left(F_{1,24.7}=5.18\right.$, $P<0.05)$.

\section{Discussion}

Energy expenditure during flight

Energy expenditure during flight, $\mathrm{e}_{\mathrm{f}}$, allometrically scaled with body mass. The observed scaling exponents range from 0.47 (for $\mathrm{C}$ flights) to 0.57 (for $\mathrm{U}$ and $\mathrm{C}$ flights combined) and lie in the range of other intra-specific measurements in birds flying for prolonged periods in a wind tunnel: Engel et al. (2006a) recorded an exponent of 0.55 in Rose Coloured Starlings (SE 0.11). Flight costs increased with $m^{0.35}$ in Red Knots (Kvist et al. 2001; CI 0.08-0.62), and with $m^{0.58}$ in Barn Swallows (Schmidt-Wellenburg et al. 2007; CI 0.190.97). These results contrast both with aerodynamic theories and with interspecific allometric comparisons. Aerodynamic theories predict a scaling exponent of 1.1-1.6 (Norberg
Table 2 The effect of $\log _{10}\left(m_{\text {transp }}\right)$ and treatment on $\log _{10}\left(\mathrm{e}_{\mathrm{f}}\right)$
${ }^{\text {a }}$ Used as reference for the other treatment effects

\begin{tabular}{lclll}
\hline Explanatory variable & Estimated effect & $F$ & $P$ & $95 \%$ CI \\
\hline Intercept & 0.053 & $F_{1,31.3}=0.048$ & & \\
$\log _{10}\left(m_{\text {transp }}\right)$ & 0.466 & $F_{1,31.3}=10.929$ & $<0.01$ & 0.178 to 0.753 \\
treatment & & $F_{1,26.8}=0.984$ & 0.330 & \\
$\mathrm{C}$ & $0^{\mathrm{a}}$ & & & \\
$\mathrm{L}$ & 0.011 & $F_{1,32.0}=0.118$ & & -0.012 to 0.033 \\
Intercept & -0.080 & $F_{1,32.0}=19.712$ & $<0.001$ & 0.291 to 0.785 \\
\hline
\end{tabular}




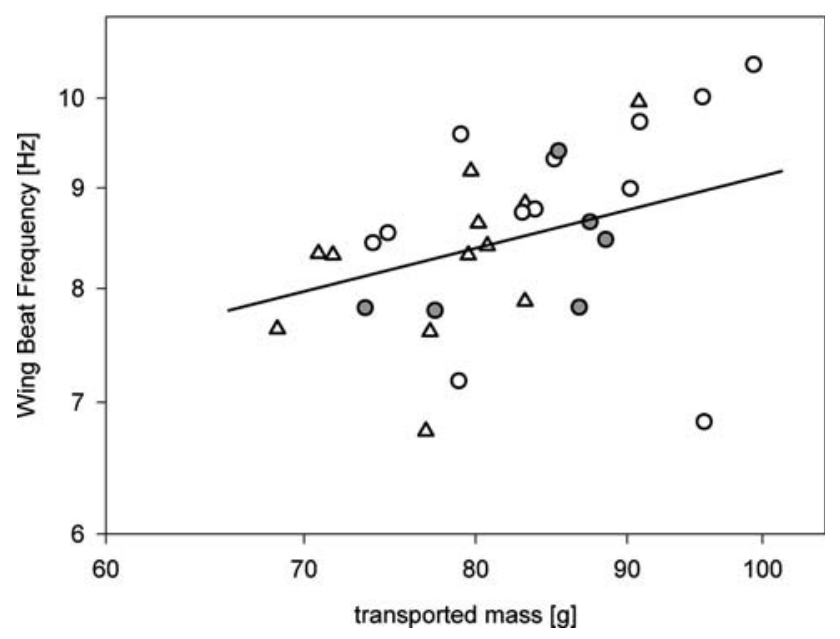

Fig. 8 Wing beat frequency (in $\mathrm{Hz}$ ) in relation to transported mass ( $\left.m_{\text {transp }}\right)$ (in $\mathrm{g}$ ) on a double-logarithmic scale. Triangles refer to $\mathrm{C}$, open circles to $\mathrm{L}_{\mathrm{S}}$, and grey circles to $\mathrm{L}_{\mathrm{L}}$ flights. The drawn line refers to Eq. 4

1990, 1996; Pennycuick 1975, 1978; Rayner 1990), interspecific allometry observed scaling exponents ranging from 0.7 to 1.9 (Butler and Bishop 2000; Masman and Klaassen 1987; Norberg 1996; Rayner 1990; Videler 2005). At the intraspecific level, $e_{f}$ increases to a lower extent than expected from theoretical considerations or extrapolated from interspecific allometry.

With regard to the harness applied, we had expected flight costs to increase, because the harness might affect aerodynamics during flight, especially with regard to the surface of the back and positions of the back feathers. Flight costs were $5.4 \%$ higher during loaded (L) compared to control (C) flights. However, we neither observed a difference between flight costs of unloaded (U) and $\mathrm{C}$ flights, nor did we detect any difference between the treatments, when $\mathrm{e}_{\mathrm{f}}$ was related to $m_{\text {transp. }}$. If the additional load in L flights were a natural increase in body mass, with Eq. 1 we would predict an elevation of $4.5 \%$ instead of the $3.4 \%$ predicted from Eq. 2.2. This difference is very small indeed. Thus, flying with a metabolically inactive load appeared to be about as expensive as flying with a naturally increased body mass. Flight costs apparently increased with transported mass $m_{\text {transp }}$ regardless of how the mass was increased.

A load of $7.4 \%$ of the birds' body mass is a rather small mass change compared to spontaneous changes of about $40 \%$ in the Rose Coloured Starling. During the pilot phase, we applied loads of up to $20 \%$, but some birds did not fly immediately or refused to fly for longer periods. As we wanted to compare $\mathrm{L}_{\mathrm{S}}$ and $\mathrm{L}_{\mathrm{L}}$, we did not train the birds to fly with a higher load and restricted the harness to $7.4 \%$. We can only speculate why birds refused to fly at all or for longer periods when an additional load of $20 \%$ of their body mass had been applied, while during the experimental phase, individuals showed spontaneous increases in body mass of up to $30 \%$ : birds might need time to get accustomed to higher loads, or they might even need some muscle training whereas they can carry lower loads easily.

Other studies on short flights have shown that birds accepted high loads of 20-27\% (Hambly et al. 2004; Nudds and Bryant 2002). In very short burst flights of $0.4 \mathrm{~s}$, hummingbirds lifted maximal loads close to twice their body mass (Chai and Millard 1997). These short flights are comparable to escape flights rather than to migratory flights. There are no data on such high loads carried during long flights.

The effect of an artificial load on flight costs has been measured in long flights in two studies on pigeons ( $\mathrm{Co}$ lumba ssp., Gessaman and Nagy 1988b; Gessaman et al. 1991) and in short flights in Zebra Finches (Taeniopygia guttata, Nudds and Bryant 2002) and Cockatiels (Nymphicus hollandicus, Hambly et al. 2004). In Tippler Pigeons (Columba livia), energy expenditure during flight was not increased when carrying a harness of 5\% of the body mass (Gessaman et al. 1991). Flight speed in these birds was increased compared to control flights (they spent 21-26\% less time flying). In a study on Homing Pigeons (Columba livia) carrying a harness of 2.5 or $5 \%$ of their body mass (Gessaman and Nagy 1988b), energy expenditure was increased by $41-52 \%$ and flight speed reduced by 15-27\% compared to control flights without a harness. Reducing or increasing flight speed was not an option for our birds flying in the wind tunnel with a set velocity.

In measurements of short flights of Zebra Finches flying with a harness of $27 \%$ of their body mass, $e_{f}$ was the same as in control flights (Nudds and Bryant 2002). Take-off speed in these birds was reduced, and mass loss during 28 h elevated. Hambly et al. (2004) observed no changes in $\mathrm{e}_{\mathrm{f}}$ in Cockatiels flying with a load of 5-20\% during $2 \mathrm{~min}$. Flight speed was reduced in flights with a $15 \%$ harness, and WBF was increased in flights with a $20 \%$ harness. It is not yet understood why measurements of $\mathrm{e}_{\mathrm{f}}$ in Tippler Pigeons, Zebra Finches and Cockatiels did not reveal an increase with load. It might be a phenomenon of short flights. In the three studies, birds could choose their own flight speed, whereas we let them fly at a given speed. Flight costs in Rose Coloured Starlings when flying without a harness but with natural variations in body mass are not dependent on flight speed (Engel et al. 2006a). It is thus unlikely that speed played a role in harnessed Rose Coloured Starlings.

\section{Breast muscle index}

The idea of a long-term morphological "adjustment" to a load is not supported by the breast muscle index. Birds in $\mathrm{L}_{\mathrm{S}}$ and $\mathrm{L}_{\mathrm{L}}$ did not significantly differ in the breast muscle index before a flight. So birds, which carried a harness for a 
prolonged period of time, did not detectably adjust breast muscle size. During a flying or fasting session, breast muscle size decreased in all treatments $\left(\mathrm{C}, \mathrm{L}_{\mathrm{S}}, \mathrm{L}_{\mathrm{L}}\right.$, and $\left.\mathrm{R}\right)$. We did not observe an effect of treatment. The decrease in breast muscle measure during a session appears to be related mainly to food and water deprivation, as it also decreased in resting birds. We did not further investigate if the pectoral muscle decreased due to the combustion of specific resources such as protein (Bauchinger and Biebach 1998). The breast muscle is of course not the only source of energy: body mass in flying birds decreased twice as much as in resting birds.

\section{Water turnover}

Water turnover in our study was about the same in all treatments. Gessaman et al. (1991) recorded higher water loss in Tippler Pigeons flying with a 5\% harness or with a control harness than flying unrestrained. Their measurements were based on DLW as well. However, their estimates of $\mathrm{rH}_{2} \mathrm{O}_{\text {out }}$ were difficult to interpret, as turnover rates were low, and birds were displaying a wider range of behaviours during the measurement, such as sunbathing, whereas our birds flew for $95 \%$ of the time measured.

\section{Wing beat frequency}

We analysed WBF as a possible behavioural adjustment to an increased body mass. Although it was positively correlated with body mass, it neither significantly explained $\mathrm{e}_{\mathrm{f}}$ nor was it related to treatment. An increase in transported mass alone, be it natural or artificial, resulted in higher WBF. The observed exponent of the correlation of WBF and $m_{\text {transp }}$ of 0.38 is similar to that observed within species (0.38 in Barn Swallows; Schmidt-Wellenburg et al. 2007) and proposed for individuals (0.5; Pennycuick 1996). We propose that possible changes in flight behaviour are not based on changes in WBF but may rather be related to changes in stroke amplitude or effective wing area.

\section{Implications}

This is the fourth study (Engel et al. 2006a; Kvist and Lindström 2001, Schmidt-Wellenburg et al. 2007) showing that energetic costs during flights of several hours increase with body mass to a lower extent than expected from interspecific comparisons and aerodynamic theories. The low increase in flight costs is reached rapidly after an additional load of $7 \%$ of the body mass had been added. Apparently, no long-term physiological changes or internal cues are necessary to optimise flight costs at a higher mass in Rose Coloured Starlings. It may rather be short-term changes such as in flight behaviour. Wing beat frequency scaled with the transported mass as expected, and we hence assume that stroke amplitude or effective wing area may be altered.

Rayner (2001) hit the mark when he wondered, "why a bird carrying a small fuel load can't operate at the high efficiency that it can reach when carrying a large load". We speculate that birds can indeed always fly with a high efficiency and that efficiency does not change with mass, at least during the migratory season. It might just be that aerodynamic considerations do not meet the reality of a flying bird and overestimate the effect of an increased mass on flight costs. An additional mass, which is either evenly distributed over the body or with an emphasis on the center of gravity, may even enhance lift of the body and tail and only slightly impair drag (Dolnik 1995). Our study thus strengthens the need for a novel aerodynamic theory of avian flight (Videler 2005).

Acknowledgments Soon after finishing this manuscript Henk Visser passed away. We are grateful that he could participate in writing this manuscript and see the progress of this project from the very beginning to its end. We thank Andrea Wittenzellner, Ninon Ballerstaedt, and Brigitte Biebach for their technical assistance during flight training and the experiments. Maria Lauterbach and Sabine Dietrich supported us with regard to flight training especially during the weekends. Berthe Verstappen determined the isotope enrichments. Gerhard Hofmann took the pictures of the callipers. David Rummel from the Institute of Statistics of the Ludwig-Maximilians-University Munich introduced us to mixed models statistics, Niels Rattenborg improved our language. We also thank Serge Daan and two reviewers for comments on the manuscript. Herbert Biebach's fascination for bird migration stimulated and enabled us to carry out this experiment in the wind tunnel. We are indebted to the late Prof. Ebo Gwinner, whose enthusiasm and thirst for knowledge were a big inspiration. The experiments were consistent with the German legislation on the protection on animals.

Open Access This article is distributed under the terms of the Creative Commons Attribution Noncommercial License which permits any noncommercial use, distribution, and reproduction in any medium, provided the original author(s) and source are credited.

\section{References}

Alerstam T, Lindström $\AA$ (1990) Optimal bird migration: the relative importance of time, energy, and safety. In: Gwinner E (ed) Bird migration. Springer, Heidelberg, pp 331-351

Battley PF, Dietz MW, Piersma T, Dekinga A, Tang S, Hulsman K (2001) Is long-distance bird flight equivalent to a high energy fast? Body composition changes in freely migrating and captive fasting great knots. Physiol Biochem Zool 74:435-449

Bauchinger U, Biebach $\mathrm{H}$ (1998) The role of protein during migration in passerine birds. Biol Cons Fauna 102:299-305

Bauchinger U, Biebach H (2001) Differential catabolism of muscle protein in Garden Warblers (Sylvia borin): flight and leg muscle act as a protein source during long-distance migration. J Comp Physiol B 171:293-301 
Bauchinger U, Wohlmann A, Biebach H (2005) Flexible remodelling of organ size during spring migration of the garden warbler (Sylvia borin). Zoology 108:97-106

Butler PJ, Bishop CM (2000) Flight. In: Whittow GC (ed) Sturkie's avian biology. Academic Press, London, pp 391-434

Chai P, Millard D (1997) Flight and size constraints: hovering performance of large hummingbirds under maximal loading. J Exp Biol 200:2757-2763

Dolnik VR (1995) The impact of increasing flight weight. In: Dolnik VR (ed) Energy and time resources in free-living birds. Nauka Publishers, St Petersburg, pp 84-85

Engel S (2005) Racing the wind. Water economy and energy expenditure in avian endurance flight. $\mathrm{PhD}$ Thesis, University of Groningen, Groningen

Engel S, Biebach H, Visser GH (2006a) Metabolic cost of avian flight in relation to flight velocity: a study in Rose-Coloured Starlings (Sturnus roseus Linnaeus). J Comp Physiol B 176:415-427

Engel S, Biebach H, Visser GH (2006b) Water and heat balance during flight in the Rose Coloured Starling (Sturnus roseus Linnaeus). Phyisol Biochem Zool 79:736-774

Gessaman JA, Nagy KA (1988a) Energy metabolism: errors in gasexchange conversion factors. Physiol Zool 61:507-513

Gessaman JA, Nagy KA (1988b) Transmitter loads affect the flight speed and metabolism of homing pigeons. Condor 90:662-668

Gessaman JA, Workman GW, Fuller MR (1991) Flight performance, energetics and water turnover of tippler pigeons with a harness and dorsal load. Condor 93:546-554

Godfrey GA (1970) A transmitter harness for small birds. IBBN 42:35

Goldspink G (1977) Mechanics and Energetics of muscle in animals of different sizes, with particular reference to the muscle fibre composition of vertebrate muscle. In: Pedley TJ (ed) Scale effects in animal locomotion. Academic Press, New York, pp 37-55

Hambly C, Harper EJ, Speakman JR (2004) The energy cost of loaded flight is substantially lower than expected due to alterations in flight kinematics. J Exp Biol 207:3969-3976

Hedenström A, Alerstam T (1997) Optimum fuel loads in migratory birds: distinguishing between time and energy minimization. J Theor Biol 189:227-234

Helseth A, Lindström A, Stervander M (2005) Southward migration and fuel deposition of Red Knots Calidris canutus. Ardea 93:213-224

Higuchi H, Ozaki K, Fujita G, Minton J, Ueta M, Soma M, Mita N (1996) Satellite tracking of White-napped Crane migration and the importance of the Korean demilitarized zone. Cons Biol 10:806-812

Hudde H. (1993) Sturnus roseus-Rosenstar. In: von Blotzheim UNG (ed) Handbuch der Vögel Mitteleuropas. Aula-Verlag, Wiesbaden, pp 2115-2144

Jenni L, Jenni-Eiermann S (1998) Fuel supply and metabolic constraints in migrating birds. J Avian Biol 29:521-528

Klaassen M, Kvist A, Lindström $\AA$ (2000) Flight costs and fuel composition of a bird migrating in a wind tunnel. Condor 102:444-451

Kvist A, Lindström $\AA$ (2001) Basal metabolic rate in migratory waders: intraindividual, intraspecific, interspecific and seasonal variation. Funct Ecol 15:465-473

Kvist A, Lindström ^̊, Green M, Piersma T, Visser GH (2001) Carrying large fuel loads during sustained bird flight is cheaper than expected. Nature 413:730-732

Lind J, Jakobsson S (2001) Body building and concurrent mass loss: flight adaptations in tree sparrows. Proc $\mathrm{R}$ Soc Lond $\mathrm{B}$ 268:1915-1919
Lifson N, McClintock RM (1966) Theory and the use of the turnover rates of body water for measuring energy and material balance. J Theor Biol 12:46-74

Masman D, Klaassen M (1987) Energy expenditure during free flight in trained and free-living Eurasian kestrels (Falco tinnunculus). Auk 104:603-616

Mufti SA, Qureshi TN (1989) Effects of overload on an avian skeletal muscle. Pak J Zool 21:25-35

Nicholls TH, Warner DW (1968) A harness for attaching radio transmitters to large owls. Bird Banding 39:209-214

Norberg UM (1990) Vertebrate flight. Mechanics, physiology, morphology, ecology and evolution. Springer, Berlin

Norberg UM (1996) The energetics of bird flight. In: Carey C (ed) Energetics of flight. Chapman \& Hall, New York, pp 199-249

Nudds RL, Bryant DM (2002) Consequences of load carrying by birds during short flights are found to be behavioural and not energetic. Am J Physiol Regul Integr Comp Physiol 283:R249-R256

Pekins PJ (1996) Effects of poncho-mounted radios on blue grouse. J Field Ornithol 59:46-50

Pennycuick CJ (1975) Mechanics of flight. In: Farner DS, King JR (eds) Avian biology. Academic Press, London, pp 1-75

Pennycuick CJ (1978) Fifteen testable predictions about bird flight. Oikos 30:165-176

Pennycuick CJ (1996) Wingbeat frequency of birds in steady cruising flight: new data and improved predictions. J Exp Biol 199:16131618

Pennycuick CJ, Rezende MA (1984) The specific power output of aerobic muscle, related to the power density of mitochondria. J Exp Biol 108:377-392

Rappole JH, Tipton A (1991) New harness design for attachment of radio transmitters to small passerines. J Field Ornithol 62:335337

Rayner JMV (1990) The mechanics of flight and bird migration performance. In: Gwinner E (ed) Bird migration. Springer, Heidelberg, pp 283-299

Rayner JMV (1999) Estimating power curves of flying vertebrates. J Exp Biol 202:3449-3461

Rayner JMV (2001) Fat and formation in flight. Nature 413:685-686

Rothe HJ, Biesel W, Nachtigall W (1987) Pigeon flight in a wind tunnel. II. Gas exchange and power requirements. J Comp Physiol B 157:99-109

Schmidt-Wellenburg CA, Biebach H, Daan S, Visser GH (2007) Energy expenditure and wing beat frequency in relation to body mass in free flying Barn Swallows (Hirundo rustica). J Comp Physiol B 177:327-337

Speakman JR (1997) Doubly labelled water. Theory and practice. Chapman \& Hall, London

Speakman JR, Visser GH, Ward S, Król E (2001) The isotope dilution method for the evaluation of body composition. In: Speakman JR (ed) Body composition analysis of animals: A handbook of nondestructive methods. Cambridge University Press, Cambridge, pp 56-98

Videler JJ (2005) Avian flight. Oxford University Press, New York

Visser GH, Dekinga A, Achterkamp B, Piersma T (2000) Ingested water equilibrates isotopically with the body water pool of a shorebird with unrivaled water fluxes. Am J Physiol Regul Integr Comp Physiol 279:R1795-R1804

Ward S, Möller U, Rayner JMV, Jackson DM, Bilo D, Nachtigall W, Speakman JR (2001) Metabolic power, mechanical power and efficiency during wind tunnel flight by the European starling Sturnus vulgaris. J Exp Biol 204:3311-3322

Weber TP, Houston AL (1997) A general model for time-minimising avian migration. J Theor Biol 185:447-458 